\title{
Monitoring and Evaluation of Teacher Professional Development for Resourceful Classroom Practices
}

\author{
Samantha Govender ${ }^{1}$, Oluwatoyin Ayodele Ajani, ${ }^{2, *}$ \\ ${ }^{1}$ Department of Curriculum and Instructional Studies, University of Zululand, South Africa \\ ${ }^{2}$ Edu-HRight Research Unit, North-West University, Potchefstroom, South Africa
}

Received December 17, 2020; Revised January 26, 2021; Accepted March 12, 2021

\begin{abstract}
Cite This Paper in the following Citation Styles
(a): [1] Samantha Govender, Oluwatoyin Ayodele Ajani, "Monitoring and Evaluation of Teacher Professional Development for Resourceful Classroom Practices," Universal Journal of Educational Research, Vol. 9, No. 4, pp. 870 879, 2021. DOI: 10.13189/ujer.2021.090421.
\end{abstract}

(b): Samantha Govender, Oluwatoyin Ayodele Ajani (2021). Monitoring and Evaluation of Teacher Professional Development for Resourceful Classroom Practices. Universal Journal of Educational Research, 9(4), 870 - 879. DOI: 10.13189/ujer.2021.090421.

Copyright $\odot 2021$ by authors, all rights reserved. Authors agree that this article remains permanently open access under the terms of the Creative Commons Attribution License 4.0 International License

\begin{abstract}
This study aimed at assessing teachers' in-service professional development activities based on teachers' perspectives of monitoring and evaluation for the programmes in South Africa. Teachers attend various scheduled professional development activities on a yearly basis to improve their classroom practices; however, the effectiveness of these activities depends on the monitoring and evaluation of teachers on the quality and nature of what they receive as professional development activities. This qualitative research study used the interpretive paradigm to collect data from three Heads of Departments in semi-structured interviews and five teachers in a focus group interview. Theory of andragogy was used as a theoretical framework to underpin teachers' views on workshops, clusters' meetings, conferences and other professional development activities they attended. Findings revealed that South African teachers were not adequately monitored and evaluated on their attendance at various professional development activities for enhanced classroom practices and seemingly, teachers do not attend professional development activities frequently every year. Findings also revealed that the contents of the professional development activities are not satisfactory to the teachers. The study, therefore, recommends that teachers should be assessed to determine their professional needs and the frequencies for these professional development activities should be increased to enhance their classroom practices.
\end{abstract}

Keywords Teacher Professional Development, Classroom Practices, Quality Education, Monitoring,
Andragogy

\section{Introduction}

Improvement of teachers' classroom practices is critical to the quality of education in South Africa. Several approaches have been adopted to enhance teachers' classroom practices; however, some of these activities have not been productive to teachers [12]. South African teachers deserve regular and quality professional development training like other professionals who constantly and consistently access professional development to improve their productivities [24]. Teachers, who are facilitators of learning, require adequate professional development that will assist them in effective curriculum delivery $[3,4]$. The state of basic education in South Africa reveals that many teachers are confronted with how best to facilitate learning and reduce learners' challenges in academic performances [26]. According to [26] classroom practices of teachers need to be improved to support and improve learners' problem-solving skills in the classroom. Similarly, teachers need to be responsible for how they can individually and collectively improve their classroom teaching to enhance their learners' performance [8].

The Department of Basic Education has continuously been emphasizing on the need for teachers to be 
professionally developed by engaging in various professional development activities, with insignificant cautions on the effectiveness of such activities on teachers' improvement [26]. Similarly, [1] and [2] posit that the "one-size-fits-all" or the cascade model of professional development activities have been established to be ineffective to improve classroom performance of the teachers in South African high schools and should be improved upon. The "one-size-fits-all" professional development activities do not address the professional needs of individual teachers, rather this approach brings together teachers with different subject backgrounds and tends to present common knowledge and skills to them in the same approach, while the cascade model promotes teachers who attend professional activities to facilitate knowledge gained in attended professional development activities to their colleagues upon return to their schools. [14] agrees that teachers in the Cascade approach may not be able to effectively deliver the knowledge and skills as received during the professional development training. Hence, these teachers may not adequately benefit from the cascade.

[24] posits that the use of professional development activities to introduce and familiarize the teachers to new curriculum policies with much emphasis on their subject pedagogy and classroom practices which can improve the curriculum delivery and learners' performance. To support [24], [14] agree that South African teachers' professional development activities are found to be irregular, inconsistent and do not adequately address the teachers' professional needs. Various challenges of in-service professional development activities of the teachers can be traced to disjointed structures of in-service professional development, absence of teachers' assessment to establish professional needs, lack of feedback on IPD activities, and many more have hindered the efficiency of in-service training [3], [4].

[10] calls for teachers need to be developed on a regular basis every year to perform efficiently and effectively in their professional duties, so as to be updated and keep abreast of the trends in their classroom practices via in-service professional development activities. Education is dynamic and there is a need for teachers to be developed to fit for learners' yearning for learning, learners believe that teachers are encyclopaedia of knowledge. [17] and [23] highlight that the classroom responsibilities of teachers and learners' expectations require that teachers access long- term, content-based, continuous and beneficial in-service professional development activities that can support teaching and learning. So also, [25] agree that the development of any nation depends on the educational change and reforms that teachers can promote based on continuous in-service professional development activities which they can access frequently. Education is the wheel to the national development of any nation, and no nation can be greater than the quality of the teachers in the education system [20].

Attempts have been made by many scholars, using different perspectives to define in-service professional development for teachers [14]. However, [29], [30] opine that there is no general definition of teacher professional development. This implies that in-service professional development is described by different educational traditions and contexts. In the context of this study, Teachers' in-service professional development includes all approaches to developing teachers for the improvement of the school system. The professional development of teachers known as staff development is to advance professional responsibilities. [18] outlines in-service professional development (IPD) as the sum of all activities, formal and informal, designed by policymakers to promote staff growth and learners' achievements. IPD entails all learning experiences that are planned to improve individual teacher, group or school which can contribute to the quality of education in the school system [12].

Therefore, in-service professional development of teachers encompasses all activities that focus on the professional needs of teachers and the institutional needs of the school system. The activities must be of immense benefits to the teacher, the school and the learners.

\section{Theoretical Framework}

Understanding the in-service of professional development activities for effective classroom entails the use of theories of learning to view the efficacy of the activities. Andragogy theory is used to underpin this study; the rationale for the adoption of adult learning is to view the usefulness of different professional activities to the teachers and the learners in the education system.

Andragogy as theory describes learning of new knowledge by teachers in professional development as adult learning, learning in this theoretical perspective sees the learner as an adult learner who is matured and has his mind ready and set for what he wants to learn [13].

[13] in [2] identifies four key assumptions which can promote appropriate learning in teachers as adult learners. These assumptions are:

i). An adult learner needs to know why he needs to learn what he needs to learn. Teacher as an adult learner knows the purpose of his learning, this enables him to concentrate and give full attention to learn the new knowledge or acquire new skills. Attendance of teachers in professional development is motivated by the need to be in that activity instead of being at the classroom.

ii). Learning is facilitated through experience. Firsthand experience or involvements in the acquisition of knowledge by teachers prompts or promote in 
teachers to gain lasting and quicker learning though their experience with others in the venues.

iii). Learning is viewed as a problem-solving. Range of activities are given to teachers to engage at in the professional development activities that are andragogically based, the experience here, aids teachers to also engage their classroom learners in problem-solving tasks.

iv). The relevance of the learning experience encourages application or adoption of IPD activities as immediate benefits of the professional development programme. Teachers want to know what benefits they stand to gain before attending such professional development.

\section{Purpose of the study}

This study aims at exploring the perspectives of teachers on the monitoring and evaluation of existing professional development activities and how these activities impact their teaching and learning in South African high schools.

\section{Research Methodology}

\subsection{Research Paradigm}

This qualitative study is interpretive in its approach; it is aimed at interpreting teachers' views on the monitoring and evaluation of in-service professional development activities [28]. Paradigm is a whole scientific system of thinking, which includes basic assumptions, questions to be answered or puzzles to be solved using research techniques [19]. The study adopted interpretivism as a trend of research approach for qualitative methods in data collection. Interpretive paradigm portrays a worldview reality that is socially constructed, complex, and ever-changing. Interpretivist paradigm and qualitative methods seek experiences, understandings and perceptions of individuals to uncover reality [19].

\subsection{Research Design}

[5] describes a research design as a plan, structure and strategy that guide and communicate decisions on study design for a study and how the information will be collected and analyzed for findings. This study adopts basic qualitative research design that helps the researchers to gather rich and in-depth information from participants and involves the interpretation of the examination of what they think or how they behave concerning certain phenomena or contextual experiences. More so, basic qualitative research design primarily exploratory and is used to gain an understanding of underlying reasons, opinions and motivation [19].

\subsection{Target Population and Sampling Procedures}

A population refers to all potential subjects who possess the attributes in which the researcher is interested, whereas, the latter, on the other hand, is the term that sets boundaries on the study units [28]. The researchers used purposive sampling technique to select the population of teachers in public high schools as participants in this study, since, sampling means taking a portion or a smaller number of units of a population as representative of that total population. The population for the study consisted of Economics teachers and Economics teaching Heads of Departments in Empangeni and Richards Bay circuits, Kwazulu-Natal Province of South Africa. Purposive sampling was used to select five Economics teachers for a focus group interview, three Economics teaching Heads of Departments in semi-structured interviews, the teachers were drawn from eight schools.

\subsection{Data Collection Methods and Procedures}

Research instruments are defined as "tools for measuring, observing or documenting data [6]. Qualitative data collection methods vary using structured or semi-structured and unstructured interview techniques [19]. A semi-structured Focus Group Discussions interview and individual interview were used for data collection.

\subsubsection{Semi-structured interviews}

A semi-structured interview allows an interviewer to ask a few pre-determined questions with follow up or probing questions which are not planned in an interview. Semi-structured interviews were used to provide answers to the research questions [28]. The participants' prior consents were obtained for the focus group interview and the individual interviews to be recorded for a verbatim account [6]. The semi-structured enabled participants to be engaged in lengthy discussions to get in-depth information.

\subsection{Data Analysis and Presentation}

Data collection from both focus group and individual interviews were audio-recorded, transcribed and coded for content thematic analysis [5].

\subsection{Ethical Considerations}

This study adhered to all ethical considerations at every stage of the research. The participants were made to participate voluntarily and were assured of their confidentiality. Pseudonyms were used for their verbatim quotations.

Demographic information of the participants as summarized in Table 1 below: 
Table 1. Participants' Demographic information

\begin{tabular}{|c|c|c|c|c|}
\hline $\begin{array}{c}\text { Research } \\
\text { participant } \\
\text { no }\end{array}$ & $\begin{array}{c}\text { Code for } \\
\text { the } \\
\text { participants }\end{array}$ & Gender & Experience & $\begin{array}{c}\text { Highest } \\
\text { qualification }\end{array}$ \\
\hline 1 & TR1 & Male & 23 & M.Ed. \\
\hline 2 & TR2 & Female & 3 & PGCE \\
\hline 3 & TR3 & Female & 7 & PGCE \\
\hline 4 & TR4 & Male & 10 & B.Ed. \\
\hline 5 & TR5 & Female & 12 & B.Ed. \\
\hline 6 & HoD1 & Female & 22 & Honours \\
\hline 7 & HoD2 & Male & 17 & M.Ed. \\
\hline 8 & HoD3 & Male & 12 & Honours \\
\hline
\end{tabular}

\section{Results and Discussion}

Collected data from the one-on-one semi-structured interviews with the three Economics teaching HoDs and a focus group discussion with five Economics teachers are discussed based on the generated themes as follow:

\subsection{Theme 1: Off-site and On-site forms of In-service Professional Development Activities for Teachers}

Findings revealed that teachers have been attending both off-site and on-site professional development to improve their classroom instructional delivery. Teachers identified that the in-service professional development activities they had attended were either on-site based or off-site based, the off-site based are those in-service professional development activities they attend outside their school premises, which are usually organized by the Department of Basic Education, while the on-site based in-service professional development activities take place within the school premises of the teachers, and are usually organised by the school management teams. The participants had these views to say:

Participant TR3 expressed that he had attended different in-service professional development activities in the last four years:

They are many in the last four years, maybe three. One within the school, the two was off-site. (TR3)

Participant TR5 expressed that teachers' in-service professional development activities are school-based and off-site based on teachers' classroom improvement:

Yes, I have attended some in the last four years. Two were within the school organized by the SMT while the other two were by the Department. (TR5)

More explanation was offered by participant HoD2 on the itinerary of teachers' professional development for the year:

I will start with outside the school, normally in the year, we have two workshops which are organized by the DoE and in the school, and we have got two, which is subject meetings, during which our department plan. This means four in all. (HoD2)

Participant HoD3 also substantiated the on-site and off-site based forms of teachers' professional development for South African teachers:

Yes, we indeed attend workshops and other forms of professional development training. Some are being organized by the school principal and the Heads of Departments, these trainings take place in our school during the school calendar while the Department through our subject advisors also organizes workshops for us usually, outside the school. (HoD3)

Findings from the participants showed that indeed there are in-service professional development activities for the teachers. These activities support the Southern African Council for Educators (2008) which regulates that teachers must engage in professional development activities to earn professional points needed for career progression. [7] recommends that teachers should be engaged in professional development activities every year to enhance learner' performance in schools. [27] affirms that teacher professional development should be varied to allow diverse teaching skills. [31] avow that diversities in the professional development of teachers' activities from both on-site and off-site are for the benefits of their learners. This concurs with [30]'s assertion that off-site and on-site professional activities enable the teachers to gain teaching skills from other teachers within and outside their schools.

\subsection{Theme 2: In-service Training Activities are not Regularly Designed for Teachers}

It has been established that teachers in South Africa do attend or participate in different in-service professional development activities, but the question is how frequently do teachers attend professional development activities every year? Participants had these to say on the frequency of their IPD every year:

Participant TR5 complained that the frequency of their IPD was low:

We indeed attend in-service training every year but we only attend once or twice a year, this is not enough for us. As teachers, we need more workshops on what to teach every term. (TR5)

Participant TR2 had a different view, according to him; he had attended three within a year:

There are many, maybe three. One within the school, the two was off-site" (TR2).

Call for an increase in the frequency of teachers' professional development activities was made by participant TR3:

I think we should have more than what we have now. Sometimes it is just once we have in the school and 
once by the Department. (TR3)

Teachers need more participation in teachers' professional development activities, year in year out. This is to improve their classroom practices. Participant HoD2 suggested an increase in the number of teachers' IPD activities by relevant stakeholders:

Presently, the numbers of workshops available to teachers every year are not many. There is need for the school to organize training or workshops for teachers, departments by departments by the SMT every term, so also the Subject advisors are to organize for teachers once every term to promote classroom practices of teachers at least every term! (HoD2)

Participant HoD1 also corroborated that the attendance of teachers at IPD activities frequently will boost their classroom teaching:

If the subject advisors can be organizing it often, it will make it easy for us to understand the topics and make learners understand the contents as well. (HoDl)

According to the participants, available in-service professional development activities to teachers are grossly inadequate. Teachers do not participate frequently in these activities. Teachers need regular in-service professional development activities to achieve and sustain quality education; there is a need for them to improve their skills and knowledge in their fields of knowledge [2]. According to [11] classroom practices of teachers become effective and productive with adequate and regular in-service professional development activities every school calendar. Findings revealed that the existing teachers' professional development activities need to be increased for more participation of teachers. This supports [16] that regular and adequate activities should be designed for teachers to attend. Similarly, [20] opines that a regular update on teaching skills is required by every teacher in today's dynamic education system. [3] avers that policymakers in the education system should support teachers' classroom practices with multiple in-service professional training or workshops to enhance learners' academic attainment.

\subsection{Theme 3: The One-Size-Fits-All Contents of IPD}

Teachers' views on what the contents or focus of the available in-service professional activities were sought for in the interviews. Participants revealed that the contents were not satisfactory to them. These they had to say:

According to participant TR2, existing IPD covers so many things:

Lots of things are included in the IPD, they tell us what to do. For instance, the chapters we are going to teach, we got the experienced teachers who will tell us what to do and then analysis of the results will also be there. (TR2)

However, some contents of the activities may not be relevant to teachers' classroom needs. Participant TR1 mentioned that some contents of IPD activities are not useful to the teachers, that what they need most is the IPD on what they teach:

We normally start with the analysis of the results, which I think is not relevant, it is not helping, we use the whole day to analyse the results of the province, national. What we need is the content of what we teach. How they can focus on these topics with lesson study how to teach the topic. (TRI)

Some topics are found to be difficult for teachers teaching Grade 12, these topics, participant HoD1 viewed should be addressed through lesson study by the experienced teachers for other teachers to learn how to teach them successfully:

Most times, especially teachers teaching grade 12, they are faced with some difficult topics like Multiplier, national income, public sector, etc. so they expect to be supported with teachings on these topics in the workshops but are often disappointed with other things in the workshops. (HoDl)

In-service professional development of teachers' activities should support classroom practices of teachers for their best performance. Participant HoD2 expressed that every teacher needs professional development that can address his professional needs:

Professional development should indeed support and improve classroom teaching, but if the contents are not appropriate to the teachers or do not meet the individual needs of the teachers, it becomes a problem. For example, a general workshop for teachers may not address their individual subject needs. (HoD2)

Contents of the professional development activities are significantly viewed by the participants as determinants of the effectiveness of IPD. Findings revealed that existing teachers' IPD activities cover different aspects for the teachers, some of which are results analysis, teaching methods, topics and chapters of different school subjects and other activities. However, teachers suggested that contents of the IPD activities should mainly focus on what they are teaching in the classrooms, topics that are challenging to them, what the learners should expect from the Matric examinations. According to [4] the effectiveness of IPD starts with the appropriate contents for the teachers, contents that can benefit the teaching and learning in the school system. This supports [2] that the needs of the teachers should be the basis for what IPD activities should cover as the contents. [20], [21], [22] posit that teachers should be evaluated to know what should be designed as IPD activities for them. [20] decries the use of one-size-fits-all for all teachers in the education 
system, as this approach does not address individual teacher's professional development needs. This implies that the professional needs of each teacher should be taken into consideration when designing IPD activities.

\subsection{Theme 4: Inadequate Monitoring and Support to Follow-up on Teachers' IPD}

There is a need for teachers to be supported and motivated with adequate follow-up. Teachers want the school management team to support their teaching and learning activities. There should be a follow-up to teaching and learning activities. Their responses were below:

Participant HoD2 decried lack of support for teachers to attend IPD activities that can improve their classroom practices:

It is so bad that not all teachers attending are being supported with the fund for transport, some of us with cars are giving money for petrol while other who need to go by public taxi are left to sort out themselves (HoD2).

Participant HoD1 expressed a lack of follow-up on teachers who attended IPD activities by the Department on a regular visit:

Yes, the DoE follow-up to check if those things mentioned in the workshops have been implemented. They come to schools to check but not regularly, at least once a term to check curriculum coverage, learners' notes, other files and records. (HoDl).

Participant HoD3 agreed that subject advisor do visit for follow-ups but the visits are not regularly done:

Yes, the subject advisors come to school to check. They do follow up; they check the documents, learners' materials and others but the follow up on IPD activities are not regular. (HoD3).

Findings from the participants revealed that teachers are not regularly followed-up on their attendance at IPD activities to ensure necessary changes in their classroom practices. [14], [20] agree that professional development for teachers can effectively transform and improve the quality of teaching and learning if teachers are monitored and followed-up on every professional development training they attend. This is to ensure implementation of what they have learnt or acquired from such training. Monitoring or following up on them enables the teachers to be assessed and recommended for other supportive professional needs. [12] and [14] posit that monitoring of teachers' professional activities promotes effective integration of IPD skills in classrooms, while it also allows teachers' classroom challenges to be identified for support.

\subsection{Theme 5: Capability of In-service Training Activities to Enhance Classroom Practices}

The main goal of in-service professional development of teachers is to improve classroom practices of teachers as well as improve their learners' performance. Participants expressed their views that various IPD activities have improved their classroom practices.

Participant TR1 was excited to express that IPD activities have improved his classroom practices and he has benefited a lot:

Yes, they have improved my teaching a lot. Like in the past, I was a teacher who was not unpacking learning but now I unpack learning for my teachings for learners to learn deeply, in our IPD they emphasize that we must always unpack learning to our learners, also before I could not teach graphs very well, I realized after the IPD that the way I was teaching it, but now I can teach graphs very well after attending IPD. Now I can say that my learners understand graphs very well. I have been assisted in the way I relate to learners in teaching. I change the way of explaining the graph. (TR1)

Another participant TR2 concurred that IPD activities have improved his confidence as a teacher, he can now teach with confidence:

I can now teach Economics with confidence and also my learners are happy now, they can now relate what they learn in their books to the real world around them. So it has helped. (T2)

Similarly, participant TR3 believed that various IPD activities have contributed to his classroom performance:

I have gained a lot of experience and I have gained a lot of information through this IPD. I have an understanding of Economics now and relate to what is happening now. (TR3)

Findings from the participants showed that the attendance of teachers at various professional development activities enables the teachers to possess updated skills and knowledge necessary for their classroom practices. [22] assert that the main objective of professional development is to ensure effective teaching and learning by providing teachers with the necessary knowledge and skills needed for effective classroom instructional delivery. [12] agrees that appropriate IPD activities allow teachers to improve their classroom practices. Learning experiences enable teachers to be resourceful in facilitating learning experiences. Teachers are provided with diverse knowledge and skills that can be adopted in classroom instructional delivery.

\subsection{Theme 6: In-service Activities during School Hours}

IPD activities are planned for teachers at different times of the year, views of teachers on how convenient these IPD activities were to them was viewed differently by the teachers. Participant TR2 expressed dissatisfaction in the timing of IPD activities which are fixed during the school hours for the teachers to leave school or abandon their 
learners:

sometimes they call us during very busy times when we supposed to revise with the learners, they will tell us that we need to attend this IPD and its very difficult to leave the learners in the school and attend this IPD, so I wish they can help to attend this IPD at the beginning or at the end of the term. (TR2)

Participant TR3 also concurred that there were times that attending IPD could be inconvenient for teachers during the busy school hours:

The other challenge we are facing is that sometimes they call us during the school hours and the principals may not allow you to leave the schools so you find out that the attendance is poor just because teachers are not attending. (TR3)

Findings from the participants revealed that teachers' participation in various professional development activities is to enhance teachers' classroom practices. [3] and [4] aver that the entry training that teachers enter the profession with, cannot sustain them in the dynamic education system of today. This supports [22] argument for continuous in-service training for teachers to support their professional roles in the education system. However, IPD activities are designed for teachers at different times of the year, some of these workshops are scheduled during the school hours while some are scheduled during their holiday. Workshops and training should be fixed at the appropriate time that will not affect their classroom practices, pulling teachers out of schools during the school hours will affect curriculum delivery as planned [12], [14], [20].

\subsection{Theme 7: Short Duration of IPD Activities}

Professional development of teachers is a career-long development; the activities for development should be varied to include long-duration to enable comprehensive learning, interactions and other supportive activities that can promote teachers' classroom efficiency. Participants expressed their worries when IPD activities are done within the one-day duration. Participant TR3 expressed the need for a longer duration for teachers' professional development activities:

I think it must be done at the beginning of the term and closing of the term. And it must not be only one day; I think two days will be fine to cover everything that will be taught in that term. (TR3)

Participant TR4 also supported that longer duration should be used for content-based IPD:

Teachers' professional development activities should be more than one day workshop, especially the ones that teachers need to be taught difficult topics we struggle to teach. We need more time to observe the lesson study from other experienced teachers who will assist us in those difficult areas. You see we need time if we are to observe many lessons during the IPD activities. (TR4)

Findings revealed that some aspects of the teachers' IPD activities may take more than a day workshop or meeting. There is a need for understanding of why teachers need to learn and how teachers need to learn what will benefit their learners. Teachers, therefore, request for a long duration of IPD activities to promote the acquisition of necessary knowledge and skills from those IPD activities. [2] submits that adequate time should be allocated to teachers' IPD activities to allow teachers' understanding and participation in the training. [20] opines that teachers' workshops and training should be varied in short and long term durations. Teachers should not be limited to professional development activities that are only for a short duration, workshops and training for a long duration can also be designed to accommodate in-depth knowledge and skills.

\subsection{Theme 8: Capability to Create Learning and Teaching Support Materials}

Teachers' IPD activities can be used to design or produce teaching and learning support materials (LTSM) that will suit learner-individual differences and peculiarity of schools. Participants indicated that IPD has been able to produce or trained them on how to create LTSM for their classroom practices. Participant TR 2 had this to say:

Yes, at the workshops some materials are shared freely to us, while at a big teachers' meeting, you see some teaching and learning materials that some publishers shade to sell, so if you have the money you buy. (TR2)

Another participant, TR4 also expressed that IPD activities promote creativity in LTSM designs for schools: In our cluster's meeting, we try to design or brainstorm on what materials and how to teach each topic to the benefit of learners. With this knowledge, I have learnt to be creative in designing teaching and learning materials for my learners. We can also ask for assistance on any aspect of the subject there. (TR4)

Using varied teaching and learning materials in classroom practices help both the teachers in facilitating learning as well as the learners in quick comprehension of a learning experience, participant TR5 had this to say:

Honestly, I have attended IPD activities that materials that helped me in teaching some difficult topics were shared to us, those we couldn't get, we were taught how we can improvise the materials, using the learners to produce these materials; thereby the classes became so interesting and learning was overwhelmingly achieved in my learners. (TR5)

Findings from the participants revealed that IPD 
activities have been beneficial to the teachers immensely; teachers have been provided with teaching and learning materials for their teaching subjects and have also been taught how to be creative so as to improvise on those that are not provided to them. [9] highlights the importance of teaching and learning materials in classroom practices of teachers; the materials do not only make teaching less stressful to the teachers but also promote quick learning in learners and make the classes interesting and interactive. [3] and [12] agree that teachers' regular participation in appropriate workshops and training allows teachers to be creative in designing learning and teaching support materials that address their school contexts.

\subsection{Theme 9: Inadequate Learning Materials for Learners to Support Teachers' Classroom Practices}

Learners' use of recommended materials such as textbooks, writing materials and other learning materials promote the effectiveness of IPD activities in the classroom practices. Teachers' views on the adequate use of these materials by the learners revealed that most learners could not afford or provide what could assist them in learning. Participant HoD1 identified inadequate resources for learners as one of the challenges that affect the effectiveness of IPD in schools:

Sometimes we need resources like books for learners and other resources which are expensive; we compile notes for them, make copies for them, in short, no adequate resources. ( $\mathrm{HoDl})$

Participant HoD2 also upheld that inadequate resources for learners remained a serious challenge of IPD:

There is a lack of resources, resources are scarce, not adequate and they slow down our work. It is a serious challenge. It doesn't make our work to go as planned; most learners can't afford the necessary materials. (HoD2)

Learning materials play a significant role in teaching and learning. According to [1], adequate provision of learning and teaching support materials (LTSM) to schools, assist teachers to utilize knowledge from teacher professional development activities effectively in their classroom practices. [11] posits that teachers' professional development activities may be waste if teachers are not provided with appropriate materials that can enhance their productivity in the classrooms. This also supports [4]'s claim that appropriate teaching and learning materials in schools promote classroom efficacy. Adequate learning materials are needed by learners to support successful teachers' classroom practices [20]. [14] asserts that inadequate learners' learning materials are a critical challenge to teachers' successful implementation of knowledge and skills gained from various in-service training/workshops.

\section{Conclusion}

Assessment of existing teachers' professional development activities in South African high schools revealed that teachers have various perspectives on the existing IPD activities available to them. Teachers indicated that the existing IPD activities were not frequently assessed by teachers; they also advised that these activities should be every term to address topics or chapters to be taught. IPD activities have been of significant benefits to classroom practices through the improvement of their teaching skills and methods [2]. However, the teachers were of opinions that timing of IPD activities should be during the school holidays so as not to disrupt their classroom teaching during the school hours. The teachers were also not satisfied with the existing follow-up on the IPD activities; they wanted more support to motivate the implementation of IPD knowledge and skills in their classroom practices.

\section{Recommendations}

This study, therefore, recommends that the Department of Basic Education and other concerned stakeholders should restructure the existing in-service professional development activities. IPD activities should focus more on what teachers are to teach every term at every grade or class. Teachers should be assessed to determine their classroom needs; follow up should be consistent with teachers after the attendance of IPD activities. Teaching and learning materials should be provided to teachers to enhance classroom practices, while all teachers should be funded by the schools to attend IPD activities frequently. The study recommends an increase in the frequency at which teachers participate in professional development activities every term and year. Parents are also encouraged to provide learning materials to support the learners. Adequate and efficient monitoring and evaluation mechanisms should be designed to drive efficiency and efficacy of teacher professional development, tools for monitoring and evaluation should be designed to support teachers and to ensure proper use of public funds expended on the various IPD programmes.

\section{REFERENCES}

[1] O.A. Ajani, "Teachers' professional development in South African high schools: How well did it suit their professional needs?" African Journal of Development Studies, vol.10, no 3, pp. 59-78, 2020.

[2] O.A. Ajani, "Needs for In-service Professional Development of Teachers to Improve Learners' Academic Performance in Sub-Saharan Africa”. Arts \& Social Science Journal, vol. 9, 
no 2, pp. 330, 2018. DOI: 10.4172/2151-6200.1000330

[3] A. Al Asmari, "Continuous Professional Development of English Language Teachers: Perception and Practices. Advances in Language and Literary Studies”, vol. 7, no.3, pp.117-124. https://eric.ed.gov/?id=EJ1127172

[4] S. Archibald, J. Coggshall, A. Croft and L. Goe, "High-quality professional development for all teachers: Effectively allocating resources". Research and Policy Brief, 2011, Washington, DC: National Comprehensive Center for Teacher Quality. Retrieved March 19, 2012, retrieved from https://eric.ed.gov/?id=ED520732.

[5] J.W. Creswell and J.D. Creswell, "Research design: Qualitative, quantitative, and mixed methods approaches". Sage publications, 2017.https://pdfs.semanticscholar.org/e1 16/0460e95677582e32f0347a9acb8bc8747b1b.pdf.

[6] J.W. Creswell, "Research design: Qualitative, quantitative, and mixed methods approaches," 2014 ( $4^{\text {th }}$ ed. $)$. Asia: Sage Press.

[7] Department of Education, "The National Policy on Framework for Teacher Education and Development in South Africa: More teachers, better teachers”, Pretoria: Government Printer, 2007.

[8] Department of Basic Education and Higher Education and Training, "Excerpt from the Integrated Strategic planning framework for teacher development in South Africa", Pretoria: Government press: 2011-2025, 2011.

[9] B. Egbo, "Teacher Capacity Building and Effective teaching and learning: A Seamless Connection" proceedings of the 2011 International Conference on Teaching, learning and Change (C) International Association for Teaching and Learning (IATEL) Co-published by Human Resource Management Academic Research Society, 2011.

[10] R.F. Elmore, "Bridging the gap Between Standards and Achievement: The Imperative Professional Development in Education, New York: Albert Shanker Institute, 2002.

[11] D.O. Fareo, "Professional Development of Teachers in Africa: A Case Study of Nigeria". The African Symposium: An Online Journal of the African Educational Research Network, vol. 13, pp. 63-68, 2013.

[12] R. Kapur, "Participation of Teachers in Continuing Professional Development”, Educational Quest: An Int. J. of Education and Applied Social Science, vol. 8, no 2, pp. 617625, 2018. DOI:10.5958/2230-7311.2017.00111.8.

[13] M. Knowles, “The adult learner" (3rd ed.). Houston, TX: Gulf Pub, 1984.

[14] M. Metcalfe, "Jika iMfundo 2015-2017: Why, what and key learnings. Learning about sustainable change in education in South Africa”, 2015. https://open.saide.ngo/repository/open saide/lsc_interior_20180511.pdf\#page $=35$

[15] P. Merliza and H. Retnawati, "Continuing professional development (CPD) for junior high school mathematics teachers: An evaluation study". REiD (Research and Evaluation in Education), vol. 4, no. 1, pp.79-93, 2018. https://journal.uny.ac.id/index.php/reid/article/view/18757.

[16] M. Murphy, "Let's change staff development to professional learning”. Principal, vol 81, pp. 16-17, 2002.
[17] K.F. Murtaza, “Teachers' Professional Development through Whole School Improvement Programme", International Journal of Business and Social Science, vol 1, no 2, pp. 213-21, 2010.http://www.ijbssnet.com/journals/V ol._1_No._2_November_2010/17.pdf

[18] W.L. Neuman, "Basics of social research", Pearson/Allyn and Bacon, 2014.

[19] H.W. Njui, "Professional Development: Promoting Quality Education in Learning Institutions in Kenya through Enhanced Teacher Capacity". European Journal of Education Studies, vol 43, no 2, 2018. https://core.ac.uk/do wnload/pdf/236101899.pdf

[20] A. Rahman and K.K. Borgohain, "Continuing professional development (CPD): A study on secondary school English teachers of Assam", Language in India, vol 14, no 12, pp. 307-320, 2014. http://www.languageinindia.com/dec2014/r ahmancpdenglishteachers1.pdf.

[21] F. Ravhuhali, A.P. Kutame and H.N. Mutshaeni, "Teachers' perceptions of the impact of continuing professional development on promoting quality teaching and learning. International Journal of Education Sciences, vol 10, no 1, pp. 1-7, 2015.

[22] V. Rivero, "Teaching your staff". American School Board Journal, vol 193, pp. 54-55, 2006.

[23] E.D. Ryan, "The Value of School-initiated Professional Development in South African Schools: A Case Paper of Two Schools in Two Gauteng Districts", Masters Dissertation, Unpublished. Johannesburg: University of the Witwatersrand, 2007.

[24] J.R. Reeves, "Secondary teacher attitudes towards including English-language learners in mainstream classrooms, Journal of Educational Research, vol 99, pp. 131-141, 2005.

[25] G.M. Steyn, "Continuing professional development for teachers in South Africa and social learning systems: conflicting conceptual frameworks of learning", University of South Africa. Pretoria, 2008.

[26] G.M. Steyn, "Continuing professional development in South African schools: Staff perceptions and the role of principals", Journal of Social Sciences, vol 28, no 1, pp. 43-53, 2011. https://doi.org/10.1080/09718923.2011.11892927.

[27] A.S. De Vos, C.S.L, Delport, C. Fouche, C. and H. Strydom, "Research at grass roots: A primer for the social science and human professions", Van Schaik Publishers, 2011. https://researchspace.auckland.ac.nz/handle/2292/11801.

[28] N. Taylor, N. Robinson, J. Hofmeyr, K. Draper and A. Johnston, "Teacher Professional Standards for South Africa. The Road to Better Performance, Development and Accountability?" Johannesburg: The Centre for Development and Enterprise, 2017. Accessed November 16, 2018 .

http://www.cde.org.za/wp-content/uploads/2017/08/CDE-In sightProfessional-Standards.pdf.

[29] C. T. Tsotetsi and S. M. G. Mahlomaholo, "Exploring strategies to strengthen continuing professional development of teachers in rural South Africa," J. High. Educ. Afric, vol. 13, no. 1-2, pp. 45-73, 2015. https://codesria.org/IMG/pdf/ 4.jhea_vol_13_1_2_15_tsotetsi_mahlomaholo.pdf 
[30] A.M. Xaso, G. Galloway and E.O. Adu, "Continuing Professional Teacher Development (CPTD): A National and International Perspective", the Anthropologist, Vol. 28, no 1-2, pp. 9-18, 2017. 